\title{
URBAN FORESTERS IDENTIFY OHIO'S TREE NEEDS
}

\author{
by Nicholas E. D’Amato', T. Davis Sydnor ${ }^{2}$, and Daniel K. Struve ${ }^{3}$
}

\begin{abstract}
In 1995 and again in 2000, Ohio's urban foresters (vegetation managers) were surveyed by mail. An article introducing them to 30 less commonly utilized trees was mailed along with each survey. The survey was designed to determine which of 120 trees Ohio's urban foresters might be requesting five years in the future (2000 and 2005). A total of 13 tree species increased in demand 100 or more while a total of 17 tree species experienced a decrease of 100 or more in demand between 1995 and 2000. In the later 2000 survey, vegetation managers were also asked to determine if they believed that demand was decreasing or increasing for each plant they requested. Demand was uniformly spread across genetic families, as only Aceraceae (17.2\%) was requested more than $9 \%$ of the time.
\end{abstract}

Key Words. Biodiversity; species selection; inventory; trees; urban forestry.

The challenge for nursery producers is to predict market demand five to ten years in advance. Nursery salespersons often say that they would carry additional material if they could be assured of a market. The costs of carrying additional inventory and the uncertainties of marketing a new plant are disincentives for nurseries to produce unproven taxa. Yet despite the potential risks, the potential benefits of having "new" taxa in inventory is great. Having a new plant in high demand that is not carried by many competitors is an ideal situation for a producer.

Many cities have experienced the problem of locating the appropriate species, proper forms, and appropriate seed sources. Our office receives numerous inquiries throughout the year regarding sources for less common trees. A case in point is the City of Columbus, Ohio, U.S. Columbus was forced to establish its own nursery to produce trees that could not be obtained from the nursery industry (Low 2001). A number of Ohio nursery owners expressed concern over a municipality using tax dollars to produce nursery stock but most of the stock produced in the Columbus city nursery was not available from commercial growers. As part of a compromise, the City of Columbus agreed to formalize its earlier decision to destroy surplus plants.

It was hoped that the survey project would accomplish several things. First, by publishing the results in both forestry and nursery publications it was hoped that the dissemination of information would help coordinate market development with nursery supply. Results of the surveys were shared with the Ohio nursery industry (Sydnor 1996; Sydnor et al. 2000). Second, we hoped to disseminate information on some less commonly grown species that had been successfully produced by the Ohio Production System (OPS) (Struve and Rhodus 1990). The OPS is a highefficiency, containerized plant production system developed at The Ohio State University that is currently being used by the commercial growers and the City of Columbus and is known generically as pot-in-pot production. The City of Columbus is using this technique to grow 2,000 to 5,000 trees per year for the next five years for city planting. The Ohio State University campus has been a testing ground for many tree species over the past 30 years; we hoped to disseminate information about trees that have done well in campus plantings and which the authors felt would have the potential for urban plantings. Third, we wanted to see that, if by disseminating information about less commonly utilized species and including such species on the survey, urban foresters would indicate a desire to try these species in future plantings. The urban forestry group at The Ohio State University has also been monitoring the stock surveys of the Ohio Nursery and Landscape Association (ONLA 2001) to see which changes, if any, are occurring in the number and types of new plants in production. Finally, it was hoped that the survey would give us a general impression of the level of diversity of trees that are being planted on city streets. The survey will also serve as a methodology exercise to find ways to improve future surveys of this type. 


\section{MATERIALS AND METHODS}

We mailed a diversity paper that included short descriptions promoting 30 less commonly grown trees that had either been raised in containers via the Ohio Production System (OPS) (Struve and Rhodus 1990; Struve et al. 1994) or that the authors felt had a strong potential for use in urban areas. This mailing was followed with the survey form containing a list of trees commonly produced and planted in Ohio plus the trees discussed in the diversity paper. The trees are listed in Table $1^{*}$. Trees described in the diversity paper have common names in bold type, while those not described have common names in normal type. We asked the respondents to first read the information on the less commonly grown species that was provided and then to complete the survey. The survey itself asked for a fiveyear projection of planting needs; thus, the 1995 survey asked for planting needs in the year 2000, and the 2000 survey for planting needs in 2005.

The authors mailed or faxed 53 surveys to the vegetation managers of cities and municipalities of various sizes throughout Ohio who were active with the Urban Forestry Section, Division of Forestry, Ohio Division of Natural Resources, and who were responsible for planting trees in their jurisdiction. The vegetation managers currently employed by or working for agencies ranging from public power organizations to parks and recreation departments to nonprofit organizations responded to the requests when presented.

The survey requested the following information from participants: (1) name and address, (2) the size of plants that they would normally purchase, (3) an estimate of the total number of trees that their organization expected to plant in 2000 or 2005, and (4) an estimate of the number of trees of each species that their city expected to plant in the respective year.

The 2000 survey differed from the 1995 survey in that it also asked respondents to indicate whether they felt that their city's need for a particular tree species on the list was increasing, decreasing, or remaining the same compared with their current and past use of the plants. This information was obtained by placing an up and down arrow next to the species and asking respondents to circle one of the arrows.

The 2000 survey asked for trees only by species, while the 1995 survey distinguished between cultivars for some species. Cultivars were dropped in favor of adding additional species during the 2000 survey. The 1995 and 2000 surveys listed a total of 120 species and cultivars (1995 survey) or species (2000 survey) of trees. Forms were then returned to T. Davis Sydnor and Nicholas E. D'Amato for tabulation.

Tree species data were grouped according to family and then genera for genera with more than a single species and where there were more than 100 trees requested for a single genus. Trees were grouped this way because insect and disease pests often attack along genus or family lines. Trends in these broader genetic areas should give additional insight and may possibly predict future trends.

Responses for change in need were weighted 1 , -1 , or 0 , depending on whether the respondent felt that the need was increasing, decreasing, or remained the same, respectively. If the forester did not indicate a need or change in need for that tree, then no value was recorded. Results were tabulated and a "need index" created from the average of the values that were submitted. A need index of 1 indicates that all respondents requesting a particular tree expected to use more of that tree type in 2005 than they were using in 2000. An index value of 0 would indicate that, on average, need for that tree would remain steady. Negative values indicate that urban foresters expected to use fewer trees of that species. Not all respondents recorded changing needs for trees that they were using. A weighted need index was also computed using the formula (Need Index/2) * (Total Respondents) ${ }^{2}$. The weighted index adjusted the need index to account for the number of respondents who identified an anticipated change in demand for a particular tree so that, for example, a response of 6:3 (increasing to decreasing) would carry a larger weight than a response of 2:1.

At the end of the 2000 survey, we asked urban foresters to estimate the total number of plants that they thought they would be planting in the year 2005. This number was used to determine any large discrepancies in the data. Discrepancies of $10 \%$ or more were resolved by contacting the respondents by telephone to resolve the excess or shortfall of plants. This information was used either to correct the results or to determine whether it would be constructive to include a place on future surveys for cities to include an estimate on the numbers of trees they would be growing for their own use or for trees that they expected to be donated or funded in some other way

*The tables are found at this end of this article. 
than a direct purchase by that city. At the end of the survey, respondents were given an opportunity to suggest a plant not in the list. This information will be used to construct future surveys.

Participants in both surveys were told that the survey results would be shared with the nursery industry in an attempt to encourage production of the species that they had requested. A five-year lead time was chosen to allow nursery producers adequate production time to have the plant on hand. Respondents were also allowed to check a box to request that a copy of the survey results be sent to them after they were published.

Finally, an inventory estimate of trees in production by Ohio nurseries was conducted. The estimate was calculated by adding up the numbers of trees that the nursery industry reported as available inventory for the year 2000. We considered the "available trees" to be trees in the size range that cities indicated they were using for new plantings. Tallying the number of newly planted trees and saleable liners that were reported yielded estimates of the number of trees available in 2005 and beyond. The numbers used were those published in the annual stock survey of the Ohio Nursery and Landscape Association (ONLA 2001).

\section{RESULTS}

Twenty-five respondents to the 53 surveys distributed in 1995 (a 47\% response rate) projected planting 17,842 trees in the year 2000 . In the 2000 survey, 29 communities out of the 53 polled responded to the survey for planting in 2005 (a 54\% return). In two communities, two separate urban foresters responded for different units of the same community in 2005 (e.g., street trees and parks). The total number of trees requested for planting declined to 15,842 for 2005. However, the year 2005 total does not include the approximately 5,000 trees being produced by The City of Columbus for outplanting in 2005 that are not being purchased from the nursery industry.

There were 26 frequently requested species (95 or more trees requested) in 11 families and 17 genera. In genera with 200 or more requests, only the Acer, Amelanchier, Fraxinus, and Tilia included more than one species (Table 2). Of the seven species of Acer that were heavily requested, four $(\times$ freemanii, platanoides, rubrum, and saccharum) are commonly grown in Ohio, while three (campestre, tartaricum, and truncatum) are less commonly grown. Other heavily requested genera with two species in the genus included Amelanchier $\times$ gran- diflora and laevis), Fraxinus (pennsylvanica and americana) and Tilia (cordata and tomentosa). The remainders of the heavily requested species were the only ones in their genus. They were Carpinus betulus, Corylus colurna, Crataegus crus-galli var. inermis, Evodia daniellii, Ginkgo biloba, Gleditsia triacanthos, Malus $\times$ cultivars, Nyssa sylvatica, Phellodendron amurense, Platanus $\times$ acerifolia, Pyrus calleryana, Syringa reticulata, and Ulmus parvifolia. Uncommonly grown (fewer than 20 Ohio growers in 2000) but heavily requested genera included Corylus colurna, Evodia daniellii, Nyssa sylvatica, and Phellodendron amurense.

Urban foresters did not request the following species: Acer saccharinum, Populus spp., Magnolia $\times$ loebneri, and Pteroceltis tartarinowii. Fewer than 20 requests were received for 13 species including Castanea mollissima, Celtis occidentalis, Pterocarya fraxinifolia, Acer palmatum, Viburnum lentago, Magnolia grandiflora, Betula papyrifera, Betula populifolia, and Ulmus davidiana. The reasons for the lack of popularity for these plants could result from real or imagined concerns such as poor service life, overplanting, lack of familiarity with the species, or to a plant's extreme site specificity.

When comparing decreases in demand between the 1995 survey and the 2000 survey, 17 tree species declined by 100 requested trees or more. An additional 16 trees declined at least 50 requested trees. This finding is a reflection of the demand change from 1995 to 2000, although the substitution of a desired plant with another tree by a municipality can skew the demand as viewed by a nursery. Five of the trees that decreased in demand are heavily grown and promoted by nurseries and include Acer rubrum, Tilia cordata, Syringa reticulata, Pyrus calleryana, and Gleditsia triacanthos. Trees available in abundance in nurseries are likely to be substituted for less commonly grown trees that might have been requested.

Increases in demand were also seen for plants included on both the 1995 and 2000 surveys. Eight plants increased demand by 100 trees or more and an additional seven plants increased demand by 50 plants or more. Three plants are being widely grown, with more than 2,000 plants estimated as available from the Ohio nursery stock survey (ONLA 2001). Malus spp., Acer platanoides, and Fraxinus americana showed increases in demand and showed wide availability.

The survey showed notable popularity of a few genera (Table 2). There were 2,719 requests for maples of various types, as Acer was the most requested genus. This finding is consistent with maple's current popular- 
ity. Fraxinus was requested 1,325 times. Malus and Tilia were requested 792 and 777 times, respectively. Amelanchier and Ulmus were requested more than 500 times each. Gleditsia declined from $768(145+623)$ requests for the year 2000 to 474 requests for the year 2005, while Pyrus decreased from $700(80+620)$ to 464 during the same period. Requests for Syringa also declined from 587 requests for 2000 to 453 requests for 2005. Despite their decline in popularity, Syringa, Pyrus, and Gleditsia were each requested more than 450 times.

The third most requested genus was Quercus, with 1,202 requests and 15 species listed. This finding is interesting because no oak species appeared in the most requested species list. It may be because the genus Quercus contained the largest number of species within a genus. Ten oak species were requested with moderate frequency (50 to 189 requests; Table 1). Elms are another surprisingly popular genus, with 573 requests. The increased availability of Dutch elm disease-resistant American elm cultivars (Valley Forge, New Harmony, and Princeton) may partially explain these numbers. Another explanation is the present popularity of cold-hardy sources of Ulmus parvifolia in moderately cold areas such as Ohio.

Foresters have been trying to diversify for years and with some success, as shown in Table 2. Only the rose, maple, and olive families contained $10 \%$ or more of total requests. Maple and rose each contained more than $17 \%$ of the requests. This preference could result in 30\% of city's tree canopy from a single family if those plants died or were destroyed at a lower rate than another species that had been planted as frequently. Forty-five percent of the mature canopy in Akron, Ohio, is already maple and is a current concern of Akron's city forester (Hahn 2001).

Diversity among species is still good, with only a single genus representing more than $9 \%$ of the requests. Acer represented $17.2 \%$ of all recorded requests both in the 1995 and 2000 surveys. Despite Akron's large maple population, respondents still requested 785 maples, or $30 \%$, of the 2,605 trees they expected to be planting in 2005. Availability in nurseries was given as the reason for the concentration of maples requested by Bill Hahn (2001) despite his expressed interest in increasing diversity in Akron. Hahn (2001) is working with individual nurseries to grow some unusual trees and then ordering them when they reach a plantable size in the nursery because Akron city code does not allow contract growing.
The response from Ohio urban foresters regarding which trees they felt were increasing, decreasing, or remaining stable in demand proved interesting. While estimates of the change in demand is a qualitative measure of the frame of mind of the urban foresters who purchase trees, we felt that this information would be particularly useful to the nursery industry. It gives forward-thinking advice and might encourage nursery production of some less commonly grown trees or give some cause for reflection where trees are being heavily planted.

Urban foresters shared their ideas as to changing needs for 103 of 120 species of trees listed in the survey for 2005 planting (Table 3). Some frequently requested plants (Pyrus calleryana, Gleditsia triacanthos, Tilia cordata, and Acer rubrum) had negative need indexes (Table 3) and showed decreasing requests for 2005 planting (Table 1). In contrast, Acer platanoides, Malus spp., and Acer saccharum were said to be decreasing in demand by urban foresters (Table 3) but were requested in larger numbers by them for 2005 planting (Table 1). This situation may indicate a future change or result from the substitution of a plant available in nurseries for an unavailable plant that was originally requested.

Some of the plants showing the largest projected increase in demand were Amelanchier laevis, Carpinus betulus, Corylus colurna, Eucommia ulmoides, Fraxinus americana, Phellodendron amurense, Quercus acutissima, Quercus imbricaria, Quercus robur, Syringa reticulata, and Ulmus americana. They all had weighted need indexes in excess of 10 (Table 3). Interestingly only Fraxinus americana, Phellodendron amurense, and Quercus acutissima showed increases in requests between the two surveys.

Another expectation was that plants in which urban foresters indicated an increasing need would include unusual plants that were being requested on an experimental basis. Of those plants with a weighted need index greater than 10, Amelanchier laevis, Corylus colurna, Eucommia ulmoides, Phellodendron amurense, Syringa reticulata, and Ulmus americana are being introduced experimentally in some of Ohio's cities (Hahn 2001; Low 2001). Results of the survey demonstrated a shift in the perceived demand for a number of tree species by Ohio's urban and community foresters. Among the trees showing the greatest increase in perceived demand were trees from the genera $N y s s a$, Ulmus, Ostrya, Carpinus, Amelanchier, Syringa, and Quercus. Some of the tree genera showing the greatest decline in demand were Pyrus, Tilia, Acer, Gleditsia, 
and Crataegus. Overall, foresters indicated a decrease in need for 11 species of trees, while they indicated an increase in need for 76 species.

There were some interesting contradictions in the results. For example, of the 11 species that foresters indicated a decreasing need for in 2005, four were ordered in greater numbers for 2005 than in 2000. The reverse was also true in a number of cases. There are several explanations for why this situation might occur. Foresters who have stopped using a particular tree (i.e., reported a 0 or blank) were unlikely to indicate a changing need for the tree. Some cities may have stopped using the tree, while others are now experimenting with it. Yet another possibility is that cities are planting based on availability; they may be using more or less of a plant currently, but foresee the opposite trend for future use.

The results of the nursery stock inventory are difficult to correlate with the urban foresters survey becaise urban foresters make up only a part of the total market for trees. Cities may also purchase trees from out of state. There were a few noticeable shortfalls, however. Acer tataricum, Celtis reticulata, Maclura pomifera inermis, Quercus stellata, Phellodendron amurense, and Ulmus wilsoniana were shade trees that may be in short supply in 2005 . Flowering trees that are projected to be in short supply for 2005 include Amelanchier laevis, Evodia daniellii, and Syringa pekinensis.

\section{DISCUSSION}

Requests for planting stock in municipal plantings shows species diversity; only Acer is requested more than $10 \%$ of the time. The lack of availability of uncommonly grown plant material of interest to urban vegetation managers was shared with producers that could be used to increase biodiversity with time enough for a supplier to respond by planting the plants in the nursery for sale some five years later (Sydnor 1996; Sydnor et al. 2000). Neither urban foresters nor nursery producers are fully aware of all of the less commonly grown species that could be planted along streets in the U.S. Midwest.

Ohio's urban vegetation managers feel that they must increase species diversity and are having some success (Hahn 2000; Low 2001). Still, less commonly utilized species are difficult to find and purchase. Further complicating the situation is the need for trees that can be grown beneath power lines for 30 or more years without cyclical pruning. Results of the survey were shared with the urban foresters so that each might know which plants are likely to be requested and will be in a better position to know which plants cities might include on a bid list.

Many nurseries feel that they must reduce their production risks by growing trees for which an established demand exists, thus limiting the diversity of their offerings. This situation increases competition among nurseries for sales of popular trees and depresses prices of those trees with established demands. In contrast, competition for uncommonly grown plants is less than for the commonly grown species, and the reduced competition offers opportunities for nursery producers to sell uncommonly grown trees at a price that would allow the recovery of a reasonable return on investment. The results of this survey indicate that cities are willing to experiment with new plant materials. It is not clear whether they are willing to pay a premium price for them. That question may be a topic for future surveys.

This project identifies those trees that are likely to be requested in fewer numbers in the future. It also identifies trees that are likely to be requested in greater numbers in the future. More important, it identifies some less common plants that have potential demand from urban foresters. This possibility requires that the producers take a risk by growing the untested species because Ohio cities do not normally allow for contract growing. Some of the trees that have been requested in this survey are ones that nurseries might not be growing. Perhaps a potential demand will encourage producers to take a risk and grow some new plants for the urban forestry community.

The results of the survey demonstrated a shift in demand for a number of tree species by Ohio's urban and community foresters. Among the genera with species showing an increase in demand of 100 or more for 2005 and beyond were trees from the genera Acer, Aesculus, Celtis, Cercis, Cladrastis, Evodia, Maclura, Malus, Nyssa, and Phellodendron. Some of the genera with species showing declines of 100 or more for 2005 were Acer, Amelanchier, Ginkgo, Ostrya, Prunus, Pyrus, Quercus, Syringa, Tilia, Ulmus, Viburnum, and Zelkova.

This survey is part of an ongoing project. Results from this survey will help to improve future studies on this topic by providing a basis for future comparisons. A future expansion of this project might include a survey of Ohio nurseries to identify the types of trees producers are currently planting and which trees they predict may experience increasing or decreasing demand. Urban foresters such as Bill Hahn are concerned 
about increasing diversity in their cities and reducing the risk of a disease that would devastate a major species such as maple. The truth is that all of us, including vegetation managers, landscape architects, and nurserymen, want reduced risks, reduced costs, and an improved quality of life for the $80 \%$ of U. S's population living and working in towns and cities of more than 30,000 people.

\section{LITERATURE CITED}

Hahn, W. 2001. Personal communication. City Forester, City of Akron, $\mathrm{OH}$.

Low, J. 2001. Personal communication. City Forester, City of Columbus, $\mathrm{OH}$.

Ohio Nursery and Landscape Association (ONLA). 2001. 2000-2001 Nursery Stock Survey. The Ohio Nursery and Landscape Association. Columbus, OH. 228 pp.

Struve, D.K., and T. Rhodus. 1990. Turning copper into gold. Am. Nurseryman. 172(4):114-125.

Struve, D.K., M.A. Arnold, R. Beeson, J.M. Ruter, S. Svenson, and W.T. Witte. 1994. The copper connection. Am. Nurseryman 179(4):52-61.

Sydnor, T.D. 1996. Your customer's needs for the year 2000. The Buckeye Educational Update, Aug. 1996. Ohio Nursery and Landscape Association, Columbus OH. 7 pp.

Sydnor, T.D., N.E. D'Amato, and D.K. Struve. 2000. Your customers' needs for the year 2005. The Buckeye Educational Update. Ohio Nursery and Landscape Association, Columbus OH. 8 pp.

${ }^{1}$ Graduate Student, Urban Forestry

${ }^{2 *}$ Professor of Urban Forestry

School of Natural Resources

The Ohio State University

2021 Coffey Road

Columbus, OH 43210-1085, U.S.

${ }^{3}$ Professor of Landscape Horticulture

Department of Horticulture and Crop Science

The Ohio State University

2001 Fyffe Court

Columbus, OH 43210, U.S.

${ }^{*}$ Corresponding author.
Résumé. En 1995, et également en 2000, les forestiers urbains (gestionnaires de végétation) de l'Ohio ont fait l'objet d'un sondage postal. Un article leur présentant 30 espèces d'arbres moins communément utilisés a été envoyé avec ce sondage. Le sondage était réalisé afin de déterminer lesquels des arbres risquaient d'être demandés cinq années plus tard (2000 et 2005) par les forestiers urbains de l'Ohio. Un total de 13 espèces a connu une hausse de la demande de 100 ou plus, tandis qu'un total de 17 espèces a connu une baisse de 100 ou plus entre 1995 et 2000. Dans le sondage plus récent de 2000, les gestionnaires de végétation ont été aussi questionnés quant à déterminer s'ils pensaient que la demande était en baisse ou en hausse pour chaque arbre qu'ils demandaient. La demande était plutôt uniformément répartie entre les familles génétiques, les acéracées $(17,2 \%)$ étant demandés plus de $9 \%$ des fois.

Zusammenfassung. 1995 und 2000 wurden die Stadtforstleute von Ohio (Vegetationsmanager) per Post befragt. Jedem Fragebogen war ein Artikel beigefügt, der sie mit 30 weniger bekannten und verwendeten Baumarten bekannt machen sollte. Die Umfrage war darauf ausgerichtet zu bestimmen, welche der 120 Baumarten die Forstleute in 5 Jahren (2000 und 2005) nachfragen würden. Insgesamt steig die Nachfrage von 13 Arten auf 100 und mehr während insgesamt 17 Baumarten einen Rückgang von 100 und mehr zwischen 1995 und 2000 erfuhren. In der Umfrage von 2000 wurden die Vegetationsmanager auch gefragt, ob sie glauben, dass die Nachfrage für die von ihnen angeforderten Pflanzen steigen oder sinken würde. Die Nachfrage war ziemlich uniform über die genetischen Familien verteilt, nur Aceraceae $(17,2 \%)$ wurde über die Zeit mehr als $9 \%$ verlangt.

Resumen. En 1995 y de nuevo en el 2000, los dasónomos urbanos de Ohio (manejadores de vegetación) fueron indagados por correo. Junto a cada formulario, un artículo los introdujo a los treinta árboles menos comunes utilizados. El estudio fue diseñado para determinar cuáles de 120 árboles podrían requerir los dasónomos urbanos de Ohio en los futuros cinco años (2000 y 2005). Un total de 13 especies de árboles incrementó en demanda 100 o más mientras un total de 17 especies de árboles experimentó una disminución de 100 o más en demanda entre 1995 y 2000 . En el estudio posterior del 2000, los manejadores de vegetación fueron indagados también para determinar si creían que la demanda estaba disminuyendo o aumentando por cada planta que ellos requerían. La demanda fue uniforme y solamente Aceraceae (17.2\%) fue requerida más del 9\% de las veces. 
Table 1. Tree species and cultivars requested by Ohio urban foresters and vegetation managers for planting in 2000 and 2005 in surveys from 1995 and 2000, respectively. Where data were not collected in one survey but were in another, N/A is substituted for missing data.

\begin{tabular}{|c|c|c|c|}
\hline Scientific name $^{z}$ & Common name ${ }^{y}$ & $\begin{array}{l}\text { Expected } \\
\text { need } 2000^{x}\end{array}$ & $\begin{array}{l}\text { Expected } \\
\text { need } 2005^{\mathrm{w}}\end{array}$ \\
\hline Acer buergeranum & Trident maple & 260 & 194 \\
\hline Acer campestre & Hedge maple & 603 & 201 \\
\hline Acer $\times$ freemanii (seedlings) & Freeman maple & 0 & 222 \\
\hline Acer $\times$ freemanii cultivars & Freeman maple selections & 229 & N/A \\
\hline Acer ginnala & Amur maple & 268 & N/A \\
\hline Acer griseum & Paperbark maple & 218 & 97 \\
\hline Acer negundo & Boxelder & 0 & N/A \\
\hline Acer palmatum & Japanese maple & 72 & 6 \\
\hline Acer platanoides & Norway maple (seedling) & 10 & 584 \\
\hline Acer platanoides cultivars & Norway maple selections & 456 & N/A \\
\hline Acer rubrum & Red maple & 75 & 344 \\
\hline Acer rubrum cultivars & Red maple selections & 348 & N/A \\
\hline Acer saccharinum & Silver maple & 0 & 0 \\
\hline Acer saccharinum cultivars & Silver maple selections & 59 & N/A \\
\hline Acer saccharum & Sugar maple & 0 & 310 \\
\hline Acer saccharum cultivars & Sugar maple selections & 262 & N/A \\
\hline Acer saccharum nigrum & Black maple & 125 & 119 \\
\hline Acer tataricum & Tatarian maple & $\mathrm{N} / \mathrm{A}$ & 366 \\
\hline Acer truncatum & Purpleblow maple & N/A & 276 \\
\hline Aesculus $\times$ carnea & Ruby red horsechestnut & $\mathrm{N} / \mathrm{A}$ & 118 \\
\hline Aesculus glabra & Ohio buckeye & 38 & 36 \\
\hline Aesculus hippocastanum & Common horsechestnut & N/A & 111 \\
\hline Aesculus octandra & Yellow buckeye & 25 & 31 \\
\hline Alnus glutinosa & European alder & 120 & 101 \\
\hline Amelanchier laevis & Allegheny serviceberry & 1039 & 307 \\
\hline Amelanchier grandiflora & Bigleaf serviceberry & N/A & 235 \\
\hline Asimina triloba & Pawpaw & 41 & 119 \\
\hline Betula alleghaniensis & Yellow birch & N/A & 26 \\
\hline Betula nigra & River birch & 70 & 108 \\
\hline Betula nigra cultivars & River birch selections & 94 & N/A \\
\hline Betula papyrifera & Paper birch & $\mathrm{N} / \mathrm{A}$ & 1 \\
\hline Betula populifolia & Grey birch & N/A & 1 \\
\hline Carpinus betulus & European hornbeam & 210 & 429 \\
\hline Carpinus betulus cultivars & European hornbeam selections & 276 & N/A \\
\hline Carya cordiformis & Bitternut hickory & 62 & 28 \\
\hline Castanea mollissima & Chinese chestnut & 0 & 4 \\
\hline Celtis laevigata & Sugar hackberry & 30 & 139 \\
\hline Celtis occidentalis & American hackberry & 57 & 12 \\
\hline Celtis reticulata & Netted hackberry & 238 & 143 \\
\hline Cercidiphyllum japonicum & Japanese katsura & 180 & 142 \\
\hline Cercis canadensis & Eastern redbud & 27 & 158 \\
\hline Chionanthus retusus & Oriental fringetree & 72 & 69 \\
\hline Cladrastis kentukea & American yellowwood & $\mathrm{N} / \mathrm{A}$ & 136 \\
\hline Cornus controversa & Pagoda dogwood & 25 & N/A \\
\hline Cornus drummondi & Drummond grey dogwood & 60 & 29 \\
\hline Cornus florida & Flowering dogwood & 9 & 28 \\
\hline Cornus kousa & Kousa dogwood (northern seed source) & 105 & 66 \\
\hline Cornus mas & Corneliancherry dogwood & 132 & 82 \\
\hline Corylus colurna & Turkish filbert & 318 & 296 \\
\hline Cotinus obovatus & American smoketree & N/A & 22 \\
\hline Crataegus crus-galli var.inermis & Thornless cockspur hawthorn & 205 & 265 \\
\hline Crataegus phaenopyrum & Washington hawthorn & 10 & 45 \\
\hline Crataegus punctata 'Ohio Pioneer' & Ohio pioneer dotted hawthorn & 90 & 90 \\
\hline
\end{tabular}


Table 1 (cont.). Tree species and cultivars requested by Ohio urban foresters and vegetation managers for planting in 2000 and 2005 in surveys from 1995 and 2000, respectively. Where data were not collected in one survey but were in another, N/A is substituted for missing data.

\begin{tabular}{|c|c|c|c|}
\hline Scientific name $^{z}$ & Common name ${ }^{y}$ & $\begin{array}{l}\text { Expected } \\
\text { need } 2000^{\mathrm{x}}\end{array}$ & $\begin{array}{l}\text { Expected } \\
\text { need } 2005^{\mathrm{w}}\end{array}$ \\
\hline Crataegus viridis 'Winter King' & Winter King green hawthorn & 112 & 25 \\
\hline Diospyros virginiana & Common persimmon & 30 & 96 \\
\hline Elaeagnus angustifolia & Russian-olive & 0 & 70 \\
\hline Eucommia ulmoides & Hardy rubbertree & 194 & 149 \\
\hline Evodia daniellii & Korean evodia & 80 & 217 \\
\hline Fagus grandifolia & American beech & N/A & 22 \\
\hline Fagus sylvatica & European beech & 80 & 83 \\
\hline Fraxinus americana & White ash & 30 & 547 \\
\hline Fraxinus americana cultivars & White ash selections & 442 & N/A \\
\hline Fraxinus excelsior & European ash & 80 & 70 \\
\hline Fraxinus pennsylvanica & Green ash & 25 & 577 \\
\hline F. pennsylvanica cultivars & Green ash selections & 529 & N/A \\
\hline Fraxinus quadrangulata & Blue ash & 167 & 131 \\
\hline Ginkgo biloba & Ginkgo & 344 & 220 \\
\hline Gleditsia triacanthos & Honeylocust & 145 & 474 \\
\hline Gleditsia triacanthos cultivars & Thornless honeylocust selections & 623 & $\mathbf{N} / \mathbf{A}$ \\
\hline Gymnocladus dioicus & Kentucky coffeetree & 140 & 102 \\
\hline Halesia carolina & Carolina silverbell & 145 & 51 \\
\hline Halesia monticola & Mountain silverbell & $\mathrm{N} / \mathrm{A}$ & 25 \\
\hline Koelreuteria paniculata & Goldenraintree (cold-hardy source) & 263 & 185 \\
\hline Liquidambar styraciflua & Sweetgum (cold-hardy source) & 156 & 135 \\
\hline Liquidambar styraciflua cultivars & Sweetgum (hardy selections) & 26 & $\mathbf{N} / \mathbf{A}$ \\
\hline Liriodendron tulipifera & Tulip poplar & 40 & 44 \\
\hline Maclura pomifera & Osage-orange (thornless males) & 30 & 154 \\
\hline Magnolia grandiflora & Southern magnolia & N/A & 2 \\
\hline Magnolia acuminata & Cucumbertree magnolia & 92 & 137 \\
\hline Magnolia $\times$ loebneri & Loebner magnolia & 47 & 0 \\
\hline Magnolia $\times$ soulangiana & Saucer magnolia & 40 & 25 \\
\hline Magnolia stellata & Star magnolia & 5 & N/A \\
\hline Malus species & Crabapples & 70 & 792 \\
\hline Malus $\times$ cultivars & Disease-resistant crabapples & 594 & N/A \\
\hline Metasequoia glyptostroboides & Dawn redwood & 88 & 55 \\
\hline Morus alba & White mulberry & 5 & 21 \\
\hline Nyssa sylvatica & Blackgum & 199 & 302 \\
\hline Ostrya virginiana & American hophornbeam & 278 & 149 \\
\hline Parrotia persica & Persian parrotia & $\mathrm{N} / \mathrm{A}$ & 40 \\
\hline Phellodendron amurense & Amur corktree & 120 & 242 \\
\hline Platanus $\times$ acerifolia & London planetree & 241 & 268 \\
\hline Platanus occidentalis & Sycamore & 50 & 42 \\
\hline Populus $\times$ cultivars & Poplar selections and cultivars & $\mathrm{N} / \mathrm{A}$ & 0 \\
\hline Prunus padus & European bird cherry & 0 & N/A \\
\hline Prunus sargentii & Sargent cherry & 210 & 64 \\
\hline Prunus serotina & Wild black cherry & 15 & 62 \\
\hline Prunus serrulata & Oriental cherry & 150 & 31 \\
\hline Ptelea trifoliata & Waferash & 59 & 20 \\
\hline Pterocarya fraxinifolia & Caucasian wingnut & 35 & 5 \\
\hline Pteroceltis tartarinowii & Tartar wingceltis & 30 & 0 \\
\hline Pterostyrax hispida & Fragrant epaulette tree & N/A & 20 \\
\hline Pyrus calleryana & Callery pear & 80 & 464 \\
\hline Pyrus calleryana cultivars & Callery pear selections & 620 & N/A \\
\hline Quercus acutissima & Sawtooth oak (cold-hardy seed source) & 155 & 189 \\
\hline Quercus alba & White oak & 151 & 36 \\
\hline Quercus bicolor & Swamp white oak & 163 & 59 \\
\hline
\end{tabular}


Table 1 (cont.). Tree species and cultivars requested by Ohio urban foresters and vegetation managers for planting in 2000 and 2005 in surveys from 1995 and 2000, respectively. Where data were not collected in one survey but were in another, N/A is substituted for missing data.

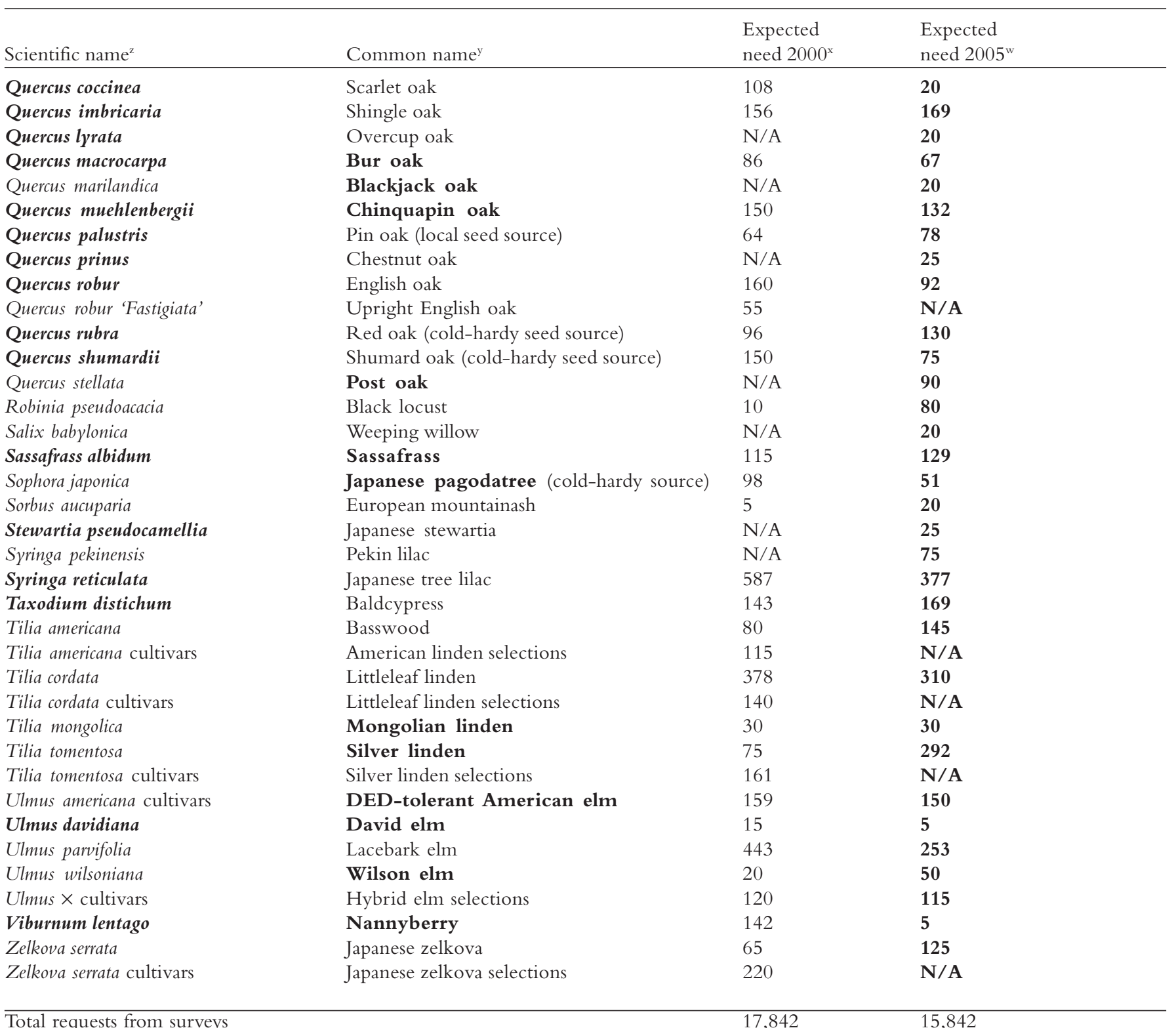

${ }^{2}$ Species in bold have been grown successfully under the Ohio Production System (Struve and Rhodus 1990; Struve et al. 1994).

'Species whose common names appear in bold were described in information packages provided to urban foresters prior to responding to the survey.

xValues are the sum of the 25 urban foresters responding to the survey in 1995.

"Values are the sum of the 29 urban foresters responding to the survey in 2000. 
Table 2. Trees are listed alphabetically by family and then alphabetically by genera when more than one species was requested in the genus or when the genus comprised 100 or more of the total requests for the 2005 planting survey. Requests for 2000 are in regular text and the 2005 requests are bolded. Families are subtotaled in bold italics when there were two or more genera in them. When data were not collected in one survey but were in another, N/A is substituted for missing data.

\begin{tabular}{|c|c|c|c|c|c|c|}
\hline Family & Genus & Common name & $\begin{array}{l}\text { Demand } \\
\text { for } 2000^{z}\end{array}$ & $\begin{array}{l}\% \text { demand } \\
\text { for } 2000\end{array}$ & $\begin{array}{l}\text { Demand } \\
\text { for } 2005^{y}\end{array}$ & $\begin{array}{l}\% \text { demand } \\
\text { for } 2005\end{array}$ \\
\hline Aceraceae & Acer & Maple & 3083 & $17.2 \%$ & 2719 & $17.2 \%$ \\
\hline Annonaceae & Asimina & Pawpaw & $\mathrm{N} / \mathrm{A}$ & $\mathrm{N} / \mathrm{A}$ & 119 & $0.8 \%$ \\
\hline \multirow[t]{4}{*}{ Betulaceae } & Betula & Birch & 164 & $0.9 \%$ & 136 & $0.9 \%$ \\
\hline & Carpinus & Hornbeam & 486 & $2.7 \%$ & 429 & $2.7 \%$ \\
\hline & Corylus & Filbert & $\mathrm{N} / \mathrm{A}$ & $\mathrm{N} / \mathrm{A}$ & 296 & $1.9 \%$ \\
\hline & Ostrya & Hophornbeam & 278 & $1.5 \%$ & 149 & $0.9 \%$ \\
\hline Family subtotal & & & 928 & $5.2 \%$ & 1010 & $6.4 \%$ \\
\hline Caprifoliacea & Viburnum & Viburnum & 142 & $0.8 \%$ & N/A & N/A \\
\hline Cercidiphyllaceae & Cercidiphyllum & Katsura & 180 & $1.0 \%$ & 142 & $0.9 \%$ \\
\hline Cornaceae & Cornus & Dogwood & 331 & $1.8 \%$ & 205 & $1.3 \%$ \\
\hline Eucommiaceae & Eucommia & Hardy rubbertree & 194 & $1.1 \%$ & 149 & $0.9 \%$ \\
\hline \multirow[t]{5}{*}{ Fabaceae } & Cercis & Redbud & N/A & $\mathrm{N} / \mathrm{A}$ & 158 & $1.0 \%$ \\
\hline & Cladrastis & Yellowwood & N/A & $\mathrm{N} / \mathrm{A}$ & 136 & $0.9 \%$ \\
\hline & Gleditsia & Honeylocust & 768 & $4.3 \%$ & 474 & $3.0 \%$ \\
\hline & Gymnocladus & Kentucky coffeetree & 140 & $0.8 \%$ & 102 & $0.6 \%$ \\
\hline & Sophora & Scholartree & 98 & $0.5 \%$ & N/A & N/A \\
\hline Family subtotal & & & 1006 & $5.6 \%$ & 870 & $5.5 \%$ \\
\hline \multirow[t]{2}{*}{ Fagaceae } & Fagus & Beech & $\mathrm{N} / \mathrm{A}$ & N/A & 105 & $0.7 \%$ \\
\hline & Quercus & Oak & 1499 & $8.3 \%$ & 1202 & $7.6 \%$ \\
\hline Family subtotal & & & 1499 & $8.3 \%$ & 1307 & $8.3 \%$ \\
\hline Ginkgoacea & Ginkgo & Ginkgo & 334 & $1.9 \%$ & 220 & $1.4 \%$ \\
\hline Hamamelidaceae & Liquidambar & Sweetgum & 182 & $1.0 \%$ & 135 & $0.9 \%$ \\
\hline Hippocastanaceae & Aesculus & Buckeye & 63 & $0.4 \%$ & 296 & $1.9 \%$ \\
\hline Lauraceae & Sassafras & Sassafras & 115 & $0.6 \%$ & 129 & $0.8 \%$ \\
\hline Magnoliaceae & Magnolia & Magnolia & 87 & $0.5 \%$ & 164 & $1.0 \%$ \\
\hline Moraceae & Maclura & Osage-orange & $\mathrm{N} / \mathrm{A}$ & $\mathrm{N} / \mathrm{A}$ & 154 & $1.0 \%$ \\
\hline Nyssaceae & $N y s s a$ & Black gum & 199 & $1.1 \%$ & 302 & $1.9 \%$ \\
\hline \multirow[t]{2}{*}{ Oleaceae } & Fraxinus & Ash & 1273 & $7.1 \%$ & 1325 & $8.4 \%$ \\
\hline & Syringa & Lilac & 587 & $3.3 \%$ & 452 & $2.9 \%$ \\
\hline Family subtotal & & & 1860 & 10.4 & 1777 & $11.2 \%$ \\
\hline Platanaceae & Platanus & Planetree & 291 & $1.6 \%$ & 310 & $2.0 \%$ \\
\hline \multirow[t]{7}{*}{ Rosaceae } & Amelanchier & Serviceberry & 1039 & $5.8 \%$ & 542 & $3.4 \%$ \\
\hline & Crataegus & Hawthorn & 417 & $2.3 \%$ & 425 & $2.7 \%$ \\
\hline & Malus & Crabapple & 664 & $3.7 \%$ & 792 & $5.0 \%$ \\
\hline & Prunus & Cherry & 375 & $2.9 \%$ & 157 & $1.0 \%$ \\
\hline & Pyrus & Pear & 700 & $3.9 \%$ & 464 & $2.9 \%$ \\
\hline & Evodia & Evodia & $\mathrm{N} / \mathrm{A}$ & $\mathrm{N} / \mathrm{A}$ & 217 & $1.4 \%$ \\
\hline & Phellodendron & Corktree & 120 & $0.7 \%$ & 242 & $1.5 \%$ \\
\hline Family subtotal & & & 3315 & $18.5 \%$ & 2839 & $17.9 \%$ \\
\hline Salicaceae & Alnus & Alder & 120 & $0.7 \%$ & 101 & $0.6 \%$ \\
\hline Sapindaceae & Koelreuteria & Goldenraintree & 283 & $1.6 \%$ & 185 & $1.2 \%$ \\
\hline Styraceae & Halesia & Silverbell & 145 & $0.8 \%$ & N/A & N/A \\
\hline Taxodiaceae & Taxodium & Baldcypress & 143 & $0.8 \%$ & 169 & $1.1 \%$ \\
\hline Tiliaceae & Tilia & Linden & 979 & $5.4 \%$ & 777 & $4.9 \%$ \\
\hline \multirow[t]{3}{*}{ Ulmaceae } & Celtis & Hackberry & 325 & $1.8 \%$ & 294 & $1.9 \%$ \\
\hline & Ulmus & Elm & 757 & $4.2 \%$ & 573 & $3.6 \%$ \\
\hline & Zelkova & Zelkova & 285 & $1.6 \%$ & 125 & $0.8 \%$ \\
\hline Family subtotal & & & 1377 & $7.6 \%$ & 995 & $6.3 \%$ \\
\hline Totals & & & 17,965 & & $15,842^{x}$ & \\
\hline
\end{tabular}

${ }^{2} 25$ urban foresters from 25 communities responding to the 1995 survey.

y 29 urban foresters from 27 communities responding to the 2000 survey.

${ }^{x}$ Does not include 5,000 trees being grown by the City of Columbus that will not be purchased from the nursery industry. 
Table 3. Plants for which urban vegetation managers indicated an increasing or decreasing demand by their unit for 2005 planting, listed alphabetically by scientific name.

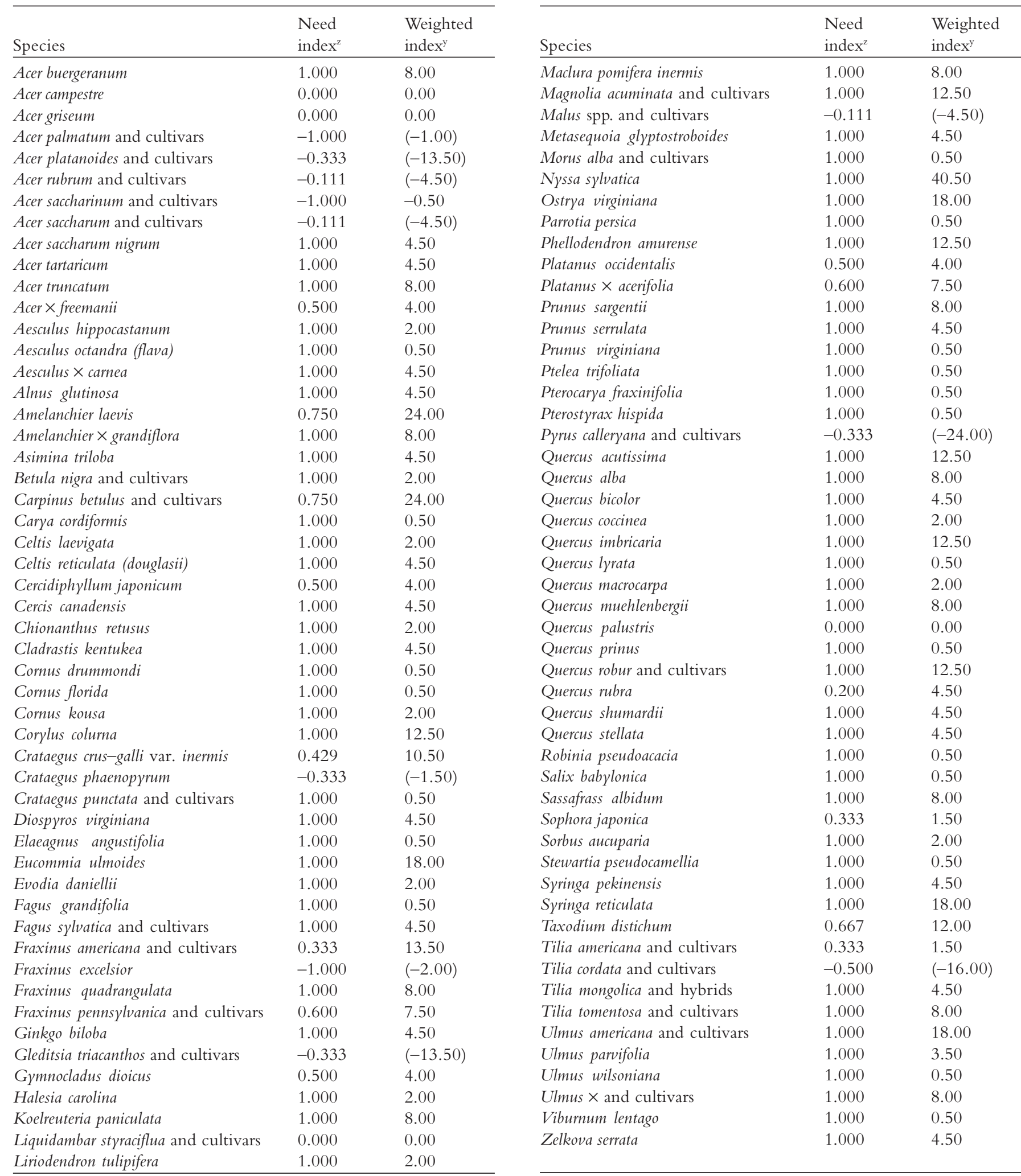

${ }^{2}$ Need index: average of responses where $1=$ increasing need, $0=$ no change, and $-1=$ decreasing need over the next five years.

'Weighted index: (Need Index/2) * (Total Respondents) ${ }^{2}$ was used to order the results. The weighted index gives greater weight to those trees where more respondents answered. 